\title{
Shear Strength and Consolidation Characteristics of Lateritic Soils: A Case of Asela Town, Oromia Regional State, Ethiopia
}

\author{
Shibiru Fekadu \\ Department of Civil Engineering, Debre Berhan University, Debre Berhan, Ethiopia \\ Email address: \\ shibe.143.f@gmail.com
}

To cite this article:

Shibiru Fekadu. Shear Strength and Consolidation Characteristics of Lateritic Soils: A Case of Asela Town, Oromia Regional State, Ethiopia. International Journal of Environmental Monitoring and Analysis. Vol. 9, No. 1, 2021, pp. 21-28. doi: 10.11648/j.ijema.20210901.13

Received: November 30, 2020; Accepted: December 10, 2020; Published: March 17, 2021

\begin{abstract}
The most important engineering properties that determine the bearing capacity of soils are shear strength or ability to resist sliding along internal surfaces within a soil mass and the consolidation characteristics. Thus, in this study the shear strength and consolidation characteristics of Asela lateritic soil is studied. The shear strength parameters (i.e. Cohesion $(C)$ and internal friction angle $(\Phi)$ ) and consolidation parameters are determined using UU triaxial and 1-D odometer tests, respectively, on disturbed soil samples remolded with different densities and water contents in order to simulate the field condition. The shear strength test was done on the cylindrical samples of $38 \mathrm{~mm}$ in diameter and a height of twice the diameter and the consolidation test were done on the samples of $75 \mathrm{~mm}$ diameter and thickness of $20 \mathrm{~mm}$. In addition, the index test (specific gravity, grain size distribution, Atterberg limits and free swell tests) also conducted on air and oven-dried samples to understand the behavior and classification of the soils. The moisture content of the studied soil ranges between $17.35-32.51 \%$, plasticity Index ranges between 11.8-26.4\%, clay fraction ranges between 25.5-61.2, free swell ranges between $20-50 \%$ and specific gravity ranges between $2.59-2.95$. The shear strength parameter, $\mathrm{C}$ and $\phi$ range from 89.63 to $161.48 \mathrm{Kpa}$ and $17^{\circ}-24^{\circ}$, respectively. The consolidation parameters: coefficient of compression ranges 0.193 to 0.581 ; coefficient of consolidation ranges 0.11 to $1.06 \mathrm{~cm}^{2} / \mathrm{sec}$, coefficient of volume compressibility ranges 0.021 to $0.34 \mathrm{~m}^{2} / \mathrm{MN}$.
\end{abstract}

Keywords: Shear Strength, Consolidation, Lateritic Soils

\section{Introduction}

The safety of any geotechnical structure is dependent on the strength of the soil. If the soil fails, a structure founded on it can collapse, endangering lives and causing economic damages. Soils fail either in tension or in shear. However, in the majority of soil mechanics problems, such as bearing capacity, lateral pressure against retaining walls, slope stability, etc., only failure in shear requires consideration. The shear strength of soils is, therefore, of paramount importance to geotechnical engineers. The shear strength along any plane is mobilized by cohesion and frictional resistance to sliding between soil particles. The cohesion and angle of friction of a soil are collectively known as shear strength parameters. [1]

In tropical and subtropical regions lateritic soils have been widely used as construction materials. Detail investigation of this type of soil is needed for the safety of civil engineering structures rest on it. Laterite was coined by Buchanan in India, and the name is derived from Latin word "Later" meaning "brick". They are classified under residual soils of highly weathered material rich in secondary oxides of iron and aluminum $\left(\mathrm{Fe}_{2} \mathrm{O}_{3}, \mathrm{Al}_{2} \mathrm{O}_{3}\right)$. Formation of laterite and lateritic soil passes through different stages that distinguishes them from other types of soils. [13]. The geotechnical properties of these soils are quite different from those soils developed in temperate or cold regions of the world. [2]. Some more descriptive terms, such as ferruginous soil, ferrallitic soils, and ferrisol are recommended in place of laterite soils [10] 
Therefore, understanding the nature of shearing resistance and consolidation of lateritic soil is necessary in order to analyze soil stability problems such as bearing capacity, slope stability, lateral pressure on earth retaining structures and settlement of structures constructed on it such as pavement and foundation of buildings. The shear resistance of soils is a result of friction and interlocking of particles, and possibly bonding or cementation at particle contacts. Due to interlocking, particulate material may expand or contract in volume as it is subject to shear strains [11]. In addition, the void ratio, density and moisture content exert a considerable influence on shear strength parameters of undisturbed as well as compacted course and fine-grained laterite soils. The shear strength parameters are very sensitive to moisture content and degree of saturation [12].

Generally the shearing resistance of soil is constituted of the following main components, the structural resistance to displacement of the soil because of the interlocking of the particles, the frictional resistance to translocation between the individual soil particles at their contact points, cohesion or adhesion between the surfaces of the soil particles [3] When the stress increased due to the construction of the foundation or the other loads, the under laying layer of the soil will be compressed, these leads to the gradual consolidation of the soil caused by deformation of soil particles, relocations of soil particles and expulsion of water or air from the void spaces. [4]

Asela is one of the areas where lateritic soils are abundantly deposited as specified by previous researcher. For example, [5] studied some of engineering properties of soil found in Asela, a thesis presented to school of gradutes study, Addis Ababa University. However, still the shear strength and consolidation characteristic; which are key parameters for computation of bearing capacity and slope stability analysis, of this soil are not studied so far. Therefore, this thesis work aimed to cover the lack of background research work on these topics, shear and consolidation characteristics of Asela lateritic soil.

\section{Objective of the Study}

The general objective of this work is to determine shear strength and consolidation characteristics of Asela lateritic soils.

\section{Methodology of the Study}

The specimen was taken at three different locations, where lateritic soil found, from seven test pits as shown in the study areas. From each test pits two samples are collected from different depth. The laboratory tests on each sample were conducted in accordance with ASTM and British laboratory manual and different pretreatment methods have been carried out. [9]

\section{Results and Discussion}

Soil is a heterogeneous material in which its properties and characteristics vary from point to point. The tests required for determination of engineering properties are generally elaborated and time consuming. Sometimes the geotechnical engineer is interested to have some rough assessment of the engineering properties without conducting elaborate tests. This is possible if index properties are determined. [6]

The index properties of soils are not of primary interest to the geotechnical engineers but which are indicative of the engineering properties [8]. The index property tests are grain size analysis, Atterberg limits, free swell and specific gravity. Mostly they can serve for identification and classification purposes. Thus, the behavior of soils should be understood by conducting those tests on physical attributes of the soil particle and soil aggregate constituents. [7]. therefore, moisture content and other types of laboratory tests determination of these types of soils needs spatial treatments. [14]. In addition, the permeability characteristics of theses soils are identified depending on laboratory test results and concluded as impermeable soils. [15]

Table 1. Moisture content determination.

\begin{tabular}{|c|c|c|c|c|}
\hline \multirow{3}{*}{$\begin{array}{l}\text { Sample } \\
\text { designation }\end{array}$} & \multirow{3}{*}{$\begin{array}{l}\text { Depth } \\
\text { (m) }\end{array}$} & \multicolumn{2}{|l|}{ moisture content } & \multirow{3}{*}{ Difference } \\
\hline & & \multicolumn{2}{|l|}{ Pretreatment } & \\
\hline & & OD $105^{\circ} \mathrm{C}$ oven tem. & AD (15 days) & \\
\hline \multirow{2}{*}{ SP1 } & 1.5 & 28.69 & 24.23 & 4.46 \\
\hline & 3 & 29.36 & 26.25 & 3.11 \\
\hline \multirow{2}{*}{ SP2 } & 1.5 & 26.97 & 25.02 & 1.95 \\
\hline & 3 & 27.93 & 26.98 & 0.95 \\
\hline \multirow{2}{*}{ SP3 } & 1.5 & 30.25 & 27.39 & 2.86 \\
\hline & 3 & 31.52 & 29.12 & 2.4 \\
\hline \multirow{2}{*}{ SP4 } & 1.5 & 29.23 & 28.42 & 0.81 \\
\hline & 3 & 31.53 & 28.52 & 3.01 \\
\hline \multirow{2}{*}{ SP5 } & 1.5 & 19.43 & 17.35 & 2.08 \\
\hline & 3 & 22.39 & 18.52 & 3.87 \\
\hline \multirow{2}{*}{ SP6 } & 1.5 & 25.01 & 20.25 & 4.76 \\
\hline & 3 & 32.51 & 27.82 & 4.69 \\
\hline \multirow{2}{*}{ SP7 } & 1.5 & 23.21 & 19.92 & 3.29 \\
\hline & 3 & 28.39 & 23.74 & 4.6 \\
\hline
\end{tabular}

Table 2. Atterberg limit.

\begin{tabular}{|c|c|c|c|c|c|c|c|}
\hline \multirow{4}{*}{$\begin{array}{l}\text { Sample } \\
\text { designation }\end{array}$} & \multirow{4}{*}{$\begin{array}{l}\text { Depth } \\
\text { (m) }\end{array}$} & \multicolumn{6}{|c|}{ Atterberg limit } \\
\hline & & \multicolumn{6}{|c|}{ Pretreatment } \\
\hline & & \multicolumn{3}{|c|}{$\mathrm{OD}\left(105^{\circ} \mathrm{C}\right)$} & \multicolumn{3}{|c|}{$\operatorname{AD}\left(50^{\circ} \mathrm{C}\right)$} \\
\hline & & $\mathbf{L L}$ & PL & PI & $\mathbf{L L}$ & PL & PI \\
\hline \multirow{2}{*}{ SP1 } & 1.5 & 47.5 & 30.2 & 17.3 & 50.0 & 35.4 & 14.6 \\
\hline & 3 & 51.2 & 32.8 & 18.4 & 58.1 & 40.6 & 17.5 \\
\hline \multirow{2}{*}{ SP2 } & 1.5 & 48.3 & 29.1 & 19.2 & 55.6 & 38.8 & 16.8 \\
\hline & 3 & 51.5 & 25.1 & 26.4 & 52.3 & 26.7 & 25.6 \\
\hline \multirow{2}{*}{ SP3 } & 1.5 & 47.6 & 35.3 & 12.3 & 52.8 & 35.09 & 17.71 \\
\hline & 3 & 40.2 & 22.9 & 17.3 & 50.4 & 25.3 & 25.1 \\
\hline \multirow{2}{*}{ SP4 } & 1.5 & 49.4 & 36.1 & 13.3 & 51.5 & 31.0 & 20.5 \\
\hline & 3 & 38.6 & 21.5 & 17.1 & 45.8 & 25.9 & 19.9 \\
\hline \multirow{2}{*}{ SP5 } & 1.5 & 54.1 & 32 & 22.1 & 52.9 & 34.6 & 18.3 \\
\hline & 3 & 45.5 & 26 & 19.5 & 48.1 & 29.7 & 18.4 \\
\hline \multirow{2}{*}{ SP6 } & 1.5 & 46.2 & 26.0 & 20.2 & 56.3 & 37 & 19.3 \\
\hline & 3 & 58.6 & 35.1 & 23.5 & 55.1 & 43.3 & 11.8 \\
\hline \multirow{2}{*}{ SP7 } & 1.5 & 45.3 & 24.5 & 20.8 & 60.4 & 21.8 & 38.6 \\
\hline & 3 & 50.1 & 25.7 & 24.4 & 60.8 & 45.4 & 15.4 \\
\hline
\end{tabular}


Table 3. Specific gravity test.

\begin{tabular}{llll}
\hline \multirow{2}{*}{$\begin{array}{l}\text { Sample } \\
\text { designation }\end{array}$} & Depth $(\mathbf{m})$ & \multicolumn{2}{l}{ Specific gravity } \\
\cline { 3 - 4 } & & Pretreatment & OD \\
\hline \multirow{2}{*}{ SP1 } & 1.5 & 2.71 & 2.74 \\
& 3 & 2.75 & 2.95 \\
SP2 & 1.5 & 2.65 & 2.77 \\
& 3 & 2.85 & 3.00 \\
SP3 & 1.5 & 2.78 & 2.89 \\
& 3 & 2.70 & 2.79 \\
SP4 & 1.5 & 2.69 & 2.72 \\
& 3 & 2.70 & 2.82 \\
SP5 & 1.5 & 2.80 & 2.95 \\
& 3 & 2.74 & 2.80 \\
SP6 & 1.5 & 2.63 & 2.70 \\
& 3 & 2.59 & 2.67 \\
SP7 & 1.5 & 2.62 & 2.69 \\
& 3 & 2.64 & 2.77 \\
\hline
\end{tabular}

Table 4. Free swelling test.

\begin{tabular}{llll}
\hline \multirow{2}{*}{$\begin{array}{llll}\text { Sample } \\
\text { designation }\end{array}$} & Depth $(\mathbf{m})$ & \multicolumn{2}{l}{ Free swelling test $(\%)$} \\
\cline { 3 - 4 } & & Pretreatment \\
\cline { 3 - 4 } SP1 & 1.5 & 28 & OD \\
\hline \multirow{2}{*}{ SP2 } & 3 & 30 & 35 \\
& 1.5 & 35 & 48 \\
SP3 & 3 & 20 & 39 \\
& 1.5 & 45 & 35 \\
SP4 & 3 & 33 & 50 \\
& 1.5 & 42 & 40 \\
SP5 & 3 & 25 & 50 \\
& 1.5 & 20 & 37 \\
SP6 & 3 & 37 & 22 \\
& 1.5 & 44 & 40 \\
SP7 & 3 & 48 & 46 \\
& 1.5 & 42 & 50 \\
\hline
\end{tabular}

Table 5. Particle size distribution of residual soils.

\begin{tabular}{|c|c|c|c|c|c|c|c|}
\hline \multirow{2}{*}{ Designation } & \multirow{2}{*}{ Depth } & \multirow{2}{*}{ Pretreatment } & \multicolumn{5}{|c|}{ Percentage amount of Particle size } \\
\hline & & & Gravel\% & Sand $\%$ & fine $\%$ & Silt\% & Clay\% \\
\hline \multirow{4}{*}{ SP1 } & \multirow{2}{*}{1.5} & OD & 0.0 & 14.1 & 85.9 & 50.37 & 35.53 \\
\hline & & $\mathrm{AD}$ & 0.0 & 10 & 90 & 48.3 & 41.7 \\
\hline & \multirow{2}{*}{3} & OD & 0.0 & 19 & 81 & 23.5 & 57.5 \\
\hline & & $\mathrm{AD}$ & 0.0 & 11.3 & 88.7 & 46.8 & 41.9 \\
\hline \multirow{4}{*}{ SP2 } & \multirow{2}{*}{1.5} & OD & 0.0 & 10.9 & 89.1 & 48.14 & 40.96 \\
\hline & & $\mathrm{AD}$ & 0.0 & 10.7 & 89.3 & 26.2 & 63.1 \\
\hline & \multirow{2}{*}{3} & OD & 0.0 & 12.3 & 87.7 & 37.6 & 50.1 \\
\hline & & $\mathrm{AD}$ & 0.0 & 12.3 & 86 & 39.05 & 48.65 \\
\hline \multirow{4}{*}{ SP3 } & \multirow{2}{*}{1.5} & OD & 0.0 & 27.8 & 72.2 & 28 & 44.2 \\
\hline & & $\mathrm{AD}$ & 0.0 & 14.3 & 85.7 & 45.1 & 40.6 \\
\hline & \multirow{2}{*}{3} & OD & 0.0 & 19.8 & 80.2 & 26.3 & 53.9 \\
\hline & & $\mathrm{AD}$ & 0.0 & 12.5 & 87.5 & 30.14 & 57.36 \\
\hline \multirow{4}{*}{ SP4 } & \multirow{2}{*}{1.5} & OD & 0.0 & 24.3 & 75.7 & 20.9 & 54.8 \\
\hline & & $\mathrm{AD}$ & 0.0 & 19.1 & 80.9 & 45.08 & 35.82 \\
\hline & \multirow{2}{*}{3} & OD & 0.0 & 21.2 & 78.8 & 31.4 & 47.4 \\
\hline & & $\mathrm{AD}$ & 0.0 & 14.7 & 85.3 & 26.33 & 58.97 \\
\hline \multirow{4}{*}{ SP5 } & \multirow{3}{*}{1.5} & OD & 0.0 & 25.7 & 74.3 & 36.1 & 38.2 \\
\hline & & $\mathrm{AD}$ & 0.0 & 17.2 & 82.8 & 57.3 & 25.5 \\
\hline & & OD & 0.0 & 12.6 & 87.4 & 28.1 & 59.3 \\
\hline & 3 & $\mathrm{AD}$ & 0.0 & 11.1 & 88.9 & 28.04 & 60.86 \\
\hline \multirow{4}{*}{ SP6 } & \multirow{2}{*}{1.5} & OD & 0.0 & 26.1 & 73.9 & 26.3 & 47.6 \\
\hline & & $\mathrm{AD}$ & 0.0 & 17.9 & 82.1 & 32.35 & 49.75 \\
\hline & \multirow{2}{*}{3} & OD & 0.0 & 30.1 & 69.9 & 25.2 & 44.7 \\
\hline & & $\mathrm{AD}$ & 0.0 & 11.7 & 88.3 & 51 & 37.3 \\
\hline \multirow{4}{*}{ SP7 } & \multirow{2}{*}{1.5} & OD & 0.0 & 13.5 & 86.5 & 38.7 & 47.8 \\
\hline & & $\mathrm{AD}$ & 0.0 & 12.1 & 87.9 & 26.7 & 61.2 \\
\hline & \multirow{2}{*}{3} & OD & 0.0 & 21 & 79 & 27.8 & 51.2 \\
\hline & & $\mathrm{AD}$ & 0.0 & 13.8 & 86.1 & 27.5 & 58.7 \\
\hline
\end{tabular}

Table 6. Classification of the soil according to AASHTO and USCS.

\begin{tabular}{|c|c|c|c|c|}
\hline \multirow{2}{*}{ Test Pit } & \multirow{2}{*}{ Depth } & \multicolumn{2}{|c|}{ Classification according to AASHTO } & \multirow{2}{*}{ Classification according to USCS } \\
\hline & & Group & Group index & \\
\hline \multirow{4}{*}{ SP1 } & \multirow{2}{*}{1.5} & A-7-5 & 17 & ML \\
\hline & & A-7-6 & 17 & $\mathrm{CH}$ \\
\hline & \multirow{2}{*}{3} & A-7-5 & 17 & $\mathrm{CH}$ \\
\hline & & A-7-5 & 19 & $\mathrm{MH}$ \\
\hline \multirow{4}{*}{ SP2 } & \multirow{2}{*}{1.5} & A-7-6 & 20 & ML \\
\hline & & A-7-6 & 20 & $\mathrm{CH}$ \\
\hline & \multirow{2}{*}{3} & A-7-6 & 19 & $\mathrm{CH}$ \\
\hline & & A-7-6 & 20 & $\mathrm{CL}$ \\
\hline
\end{tabular}




\begin{tabular}{|c|c|c|c|c|}
\hline \multirow{2}{*}{ Test Pit } & \multirow{2}{*}{ Depth } & \multicolumn{2}{|c|}{ Classification according to AASHTO } & \multirow{2}{*}{ Classification according to USCS } \\
\hline & & Group & Group index & \\
\hline \multirow{4}{*}{ SP3 } & \multirow{2}{*}{1.5} & A-7-6 & 18 & $\mathrm{CL}$ \\
\hline & & A-7-5 & 18 & MH \\
\hline & \multirow{2}{*}{3} & A-7-6 & 14 & $\mathrm{CL}$ \\
\hline & & A-7-6 & 17 & $\mathrm{CH}$ \\
\hline \multirow{4}{*}{ SP4 } & \multirow{2}{*}{1.5} & A-7-6 & 12 & $\mathrm{CL}$ \\
\hline & & A-7-5 & 19 & MH \\
\hline & \multirow{2}{*}{3} & A-7-6 & 13 & $\mathrm{CL}$ \\
\hline & & A-7-6 & 19 & $\mathrm{CL}$ \\
\hline \multirow{4}{*}{ SP5 } & \multirow{2}{*}{1.5} & A-7-6 & 17 & $\mathrm{CH}$ \\
\hline & & A-7-6 & 18 & MH \\
\hline & \multirow{2}{*}{3} & A-7-6 & 18 & $\mathrm{CL}$ \\
\hline & & A-7-6 & 19 & $\mathrm{CL}$ \\
\hline \multirow{4}{*}{ SP6 } & \multirow{2}{*}{1.5} & A-7-6 & 20 & $\mathrm{CH}$ \\
\hline & & A-7-6 & 15 & $\mathrm{CL}$ \\
\hline & \multirow{2}{*}{3} & A-7-6 & 16 & MH \\
\hline & & A-7-6 & 18 & $\mathrm{CL}$ \\
\hline \multirow{4}{*}{ SP7 } & \multirow{2}{*}{1.5} & A-7-6 & 19 & $\mathrm{CL}$ \\
\hline & & A-7-6 & 19 & $\mathrm{CH}$ \\
\hline & \multirow{2}{*}{3} & A-7-6 & 19 & $\mathrm{CH}$ \\
\hline & & A-7-6 & 20 & $\mathrm{CH}$ \\
\hline
\end{tabular}

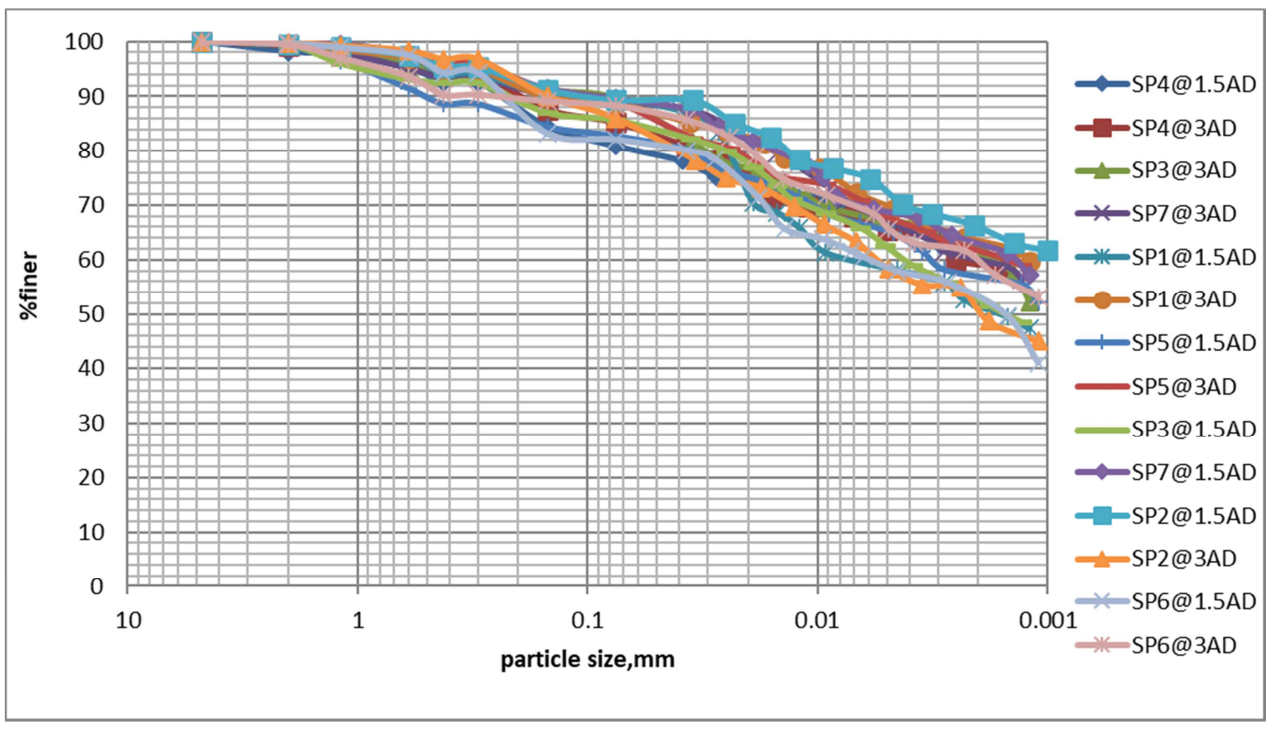

Figure 1. Particle size analysis for AD samples.

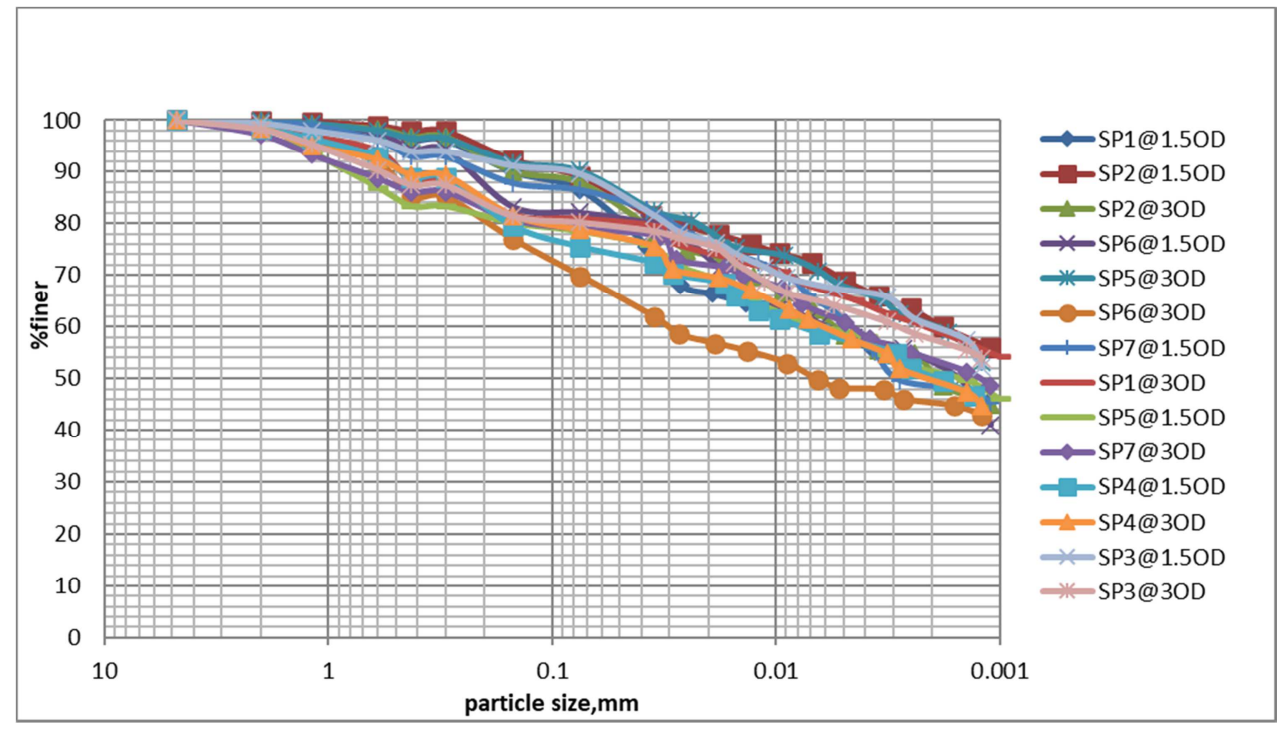

Figure 2. Particle size analysis for OD samples. 


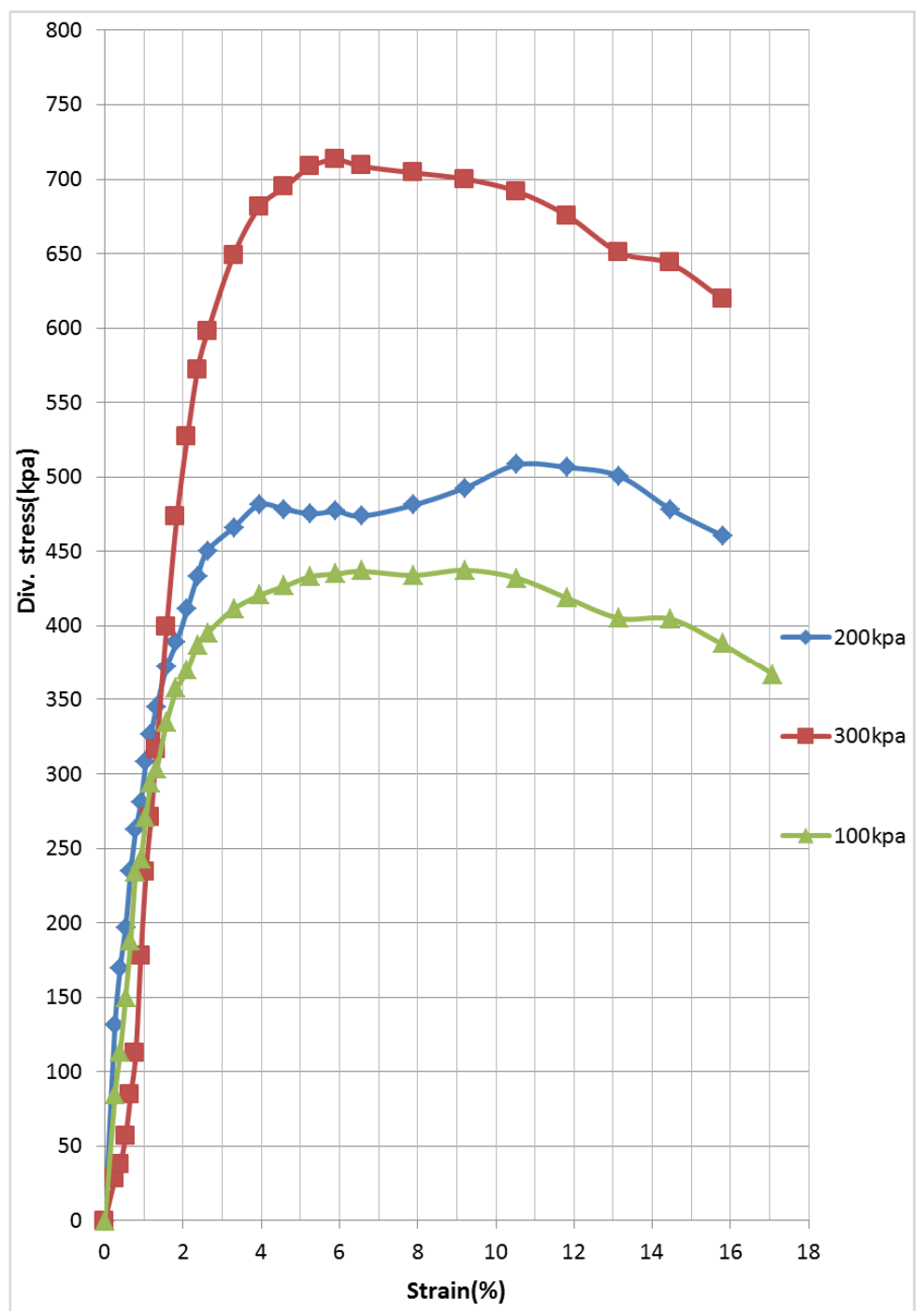

Figure 3. Axial stress vs. strain of SP1 at $3 m$ dept.

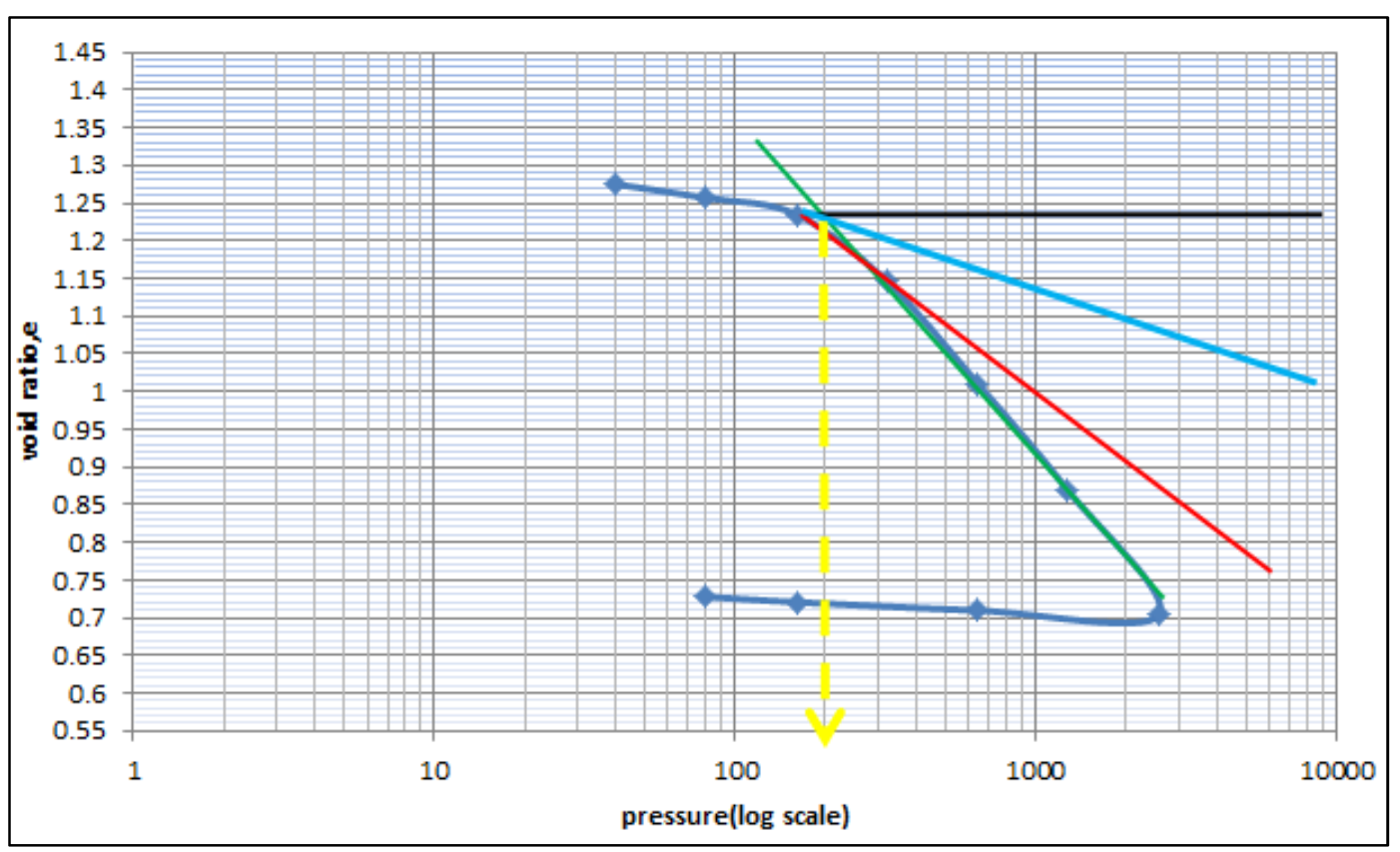

Figure 4. Results of laboratory consolidation parameters tests graphs. 
Table 7. $C$ and $\Phi$ values of soils remolded with OMC and MDD under UU test.

\begin{tabular}{llllllll}
\hline TP & Depth $(\mathbf{m})$ & Treatment condition & Soil description & MDD (g/cc) & OMC (g/cc) & Cu & $\boldsymbol{\emptyset}^{\mathbf{0}}$ \\
\hline SP1 & 3 & OD & CH & 1.8 & 25 & 161.48 \\
SP2 & 1.5 & AD & CH & 1.4 & 36 & 126.56 \\
SP3 & 1.5 & OD & CL & 1.38 & 26.5 & 19 \\
SP4 & 1.5 & OD & CL & 1.49 & 28.56 & 124.3 \\
SP5 & 3 & OD & CL & 1.48 & 30 & 100.69 \\
SP6 & 1.5 & AD & CH & 1.65 & 27.85 & 14.46 \\
SP7 & 3 & OD & CH & 1.75 & 35.36 & 157.81 \\
\hline
\end{tabular}

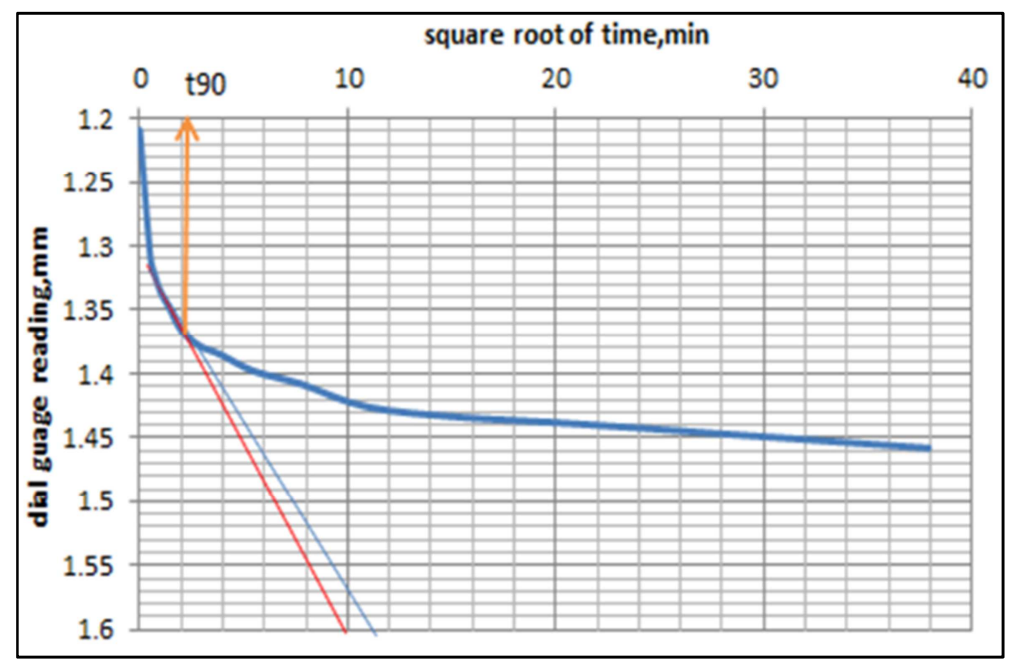

Figure 5. Results of laboratory consolidation parameters tests graphs.

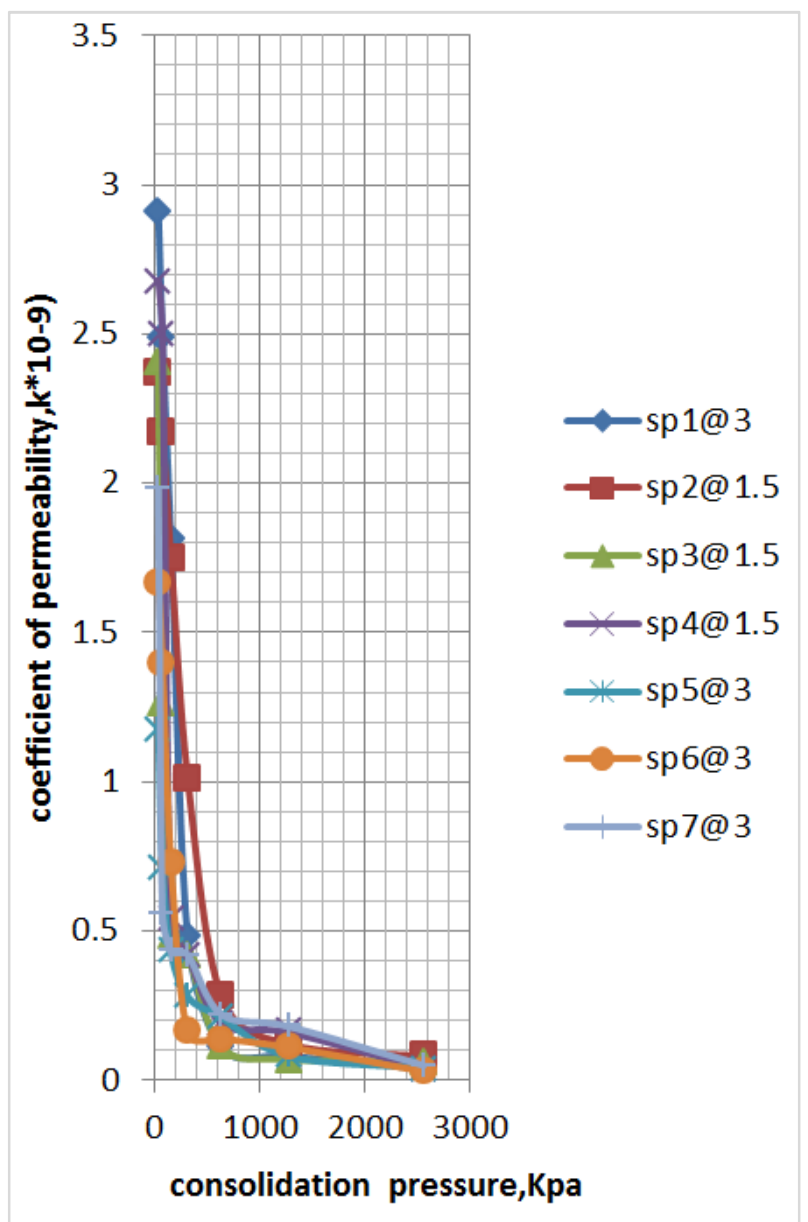

Figure 6. Relationship between consolidation pressure and coefficient of permeability. 


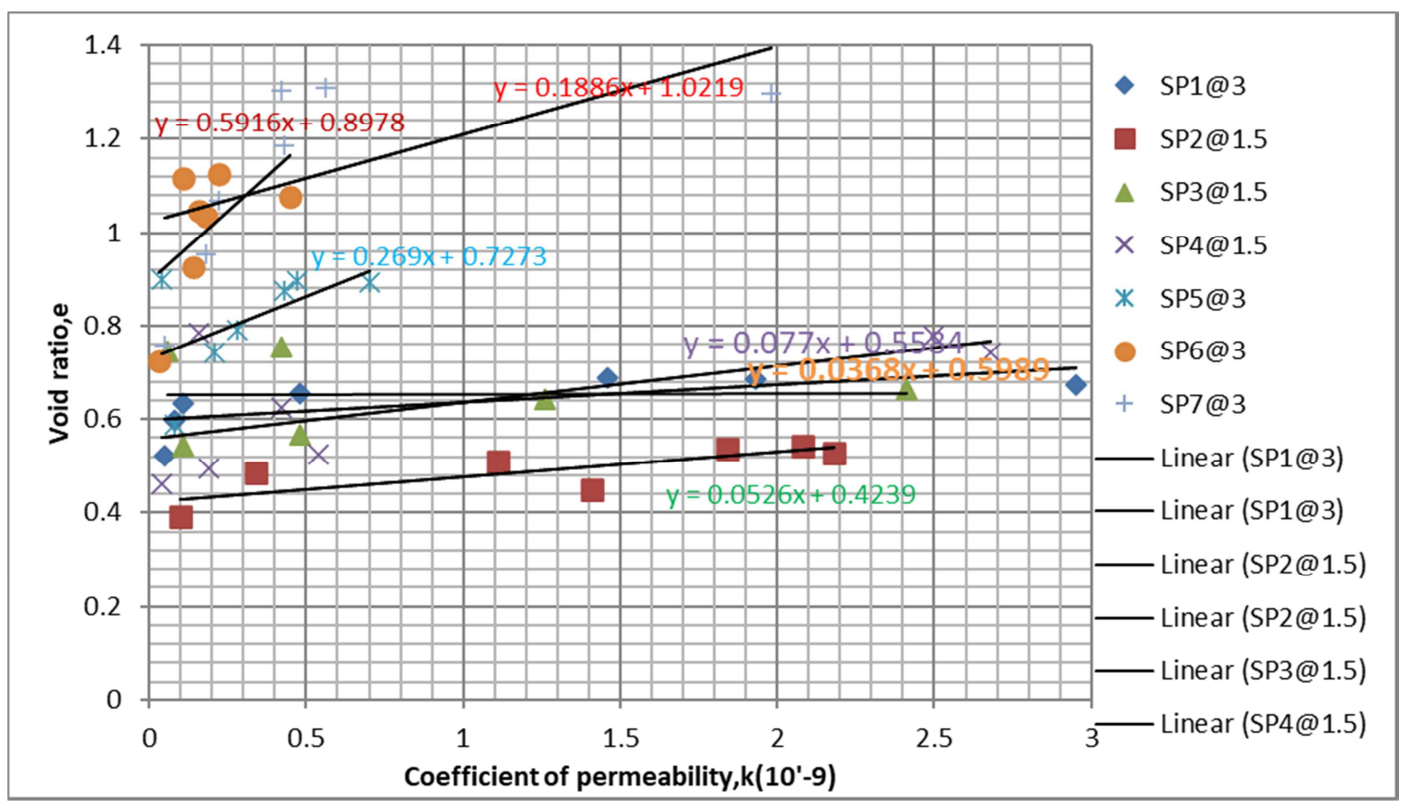

Figure 7. Relationship between void ratio and coefficient of permeability.

\section{Conclusion}

The index property, shear strength and consolidation characteristics of Asela lateritic soils are investigated on disturbed soils after molding, from which different results are obtained. Based on the test results, the following conclusions are drawn:

1. The General soil classification systems, USCS and AASHTO, show that the lateritic soils of Asela are fine grained and unsuitable as construction material and sub grade material.

2. Almost all the samples have free swell value of less than $50 \%$. This shows the soil in the study area is nonexpansive with free swell value ranging from $22 \%$ to $50 \%$.

3. From the mode of formation and comparisons of gradation charts, Asela soil could be grouped as Ferrisol soil.

4. The values of compression index, $\mathrm{Cc}$, and coefficient of consolidation, $\mathrm{C}_{\mathrm{V}}$, of Asela lateritic soil as determined from the consolidation test on disturbed samples ranges from $0.193-0.581$ and $0.11-1.06 \mathrm{~cm}^{2} / \mathrm{sec}$, respectively. The values of the consolidation parameters of the studied soils are relatively small, suggesting the soils are characterized by low compressibility and slow rate of consolidation.

5. The shear strength parameters $\mathrm{Cu}$ and $\Phi$ values obtained from UU test range from 89.63 to $161.48 \mathrm{kPa}$ and from $17^{\circ}$ to $24^{\circ}$ respectively.

6 . The soils under the study are over consolidated soils as the over consolidation ratio (OCR) is higher than one

\section{Recommendation}

1. To increase the level of accuracy of the shear strength characteristics of Asela lateritic soils it is recommended to conduct further tests by using $\mathrm{CU}$ tests with more number of samples that are undisturbed.

2. In this thesis the consolidation parameters of the soil under studies are determined from disturbed samples. Thus it is recommended that to study the consolidation parameters of the considered soil on undisturbed samples for more accuracy.

3. The maximum cell pressure applied in this study is $300 \mathrm{kpa}$; further detailed

4. investigation has to be carried out by using higher cell pressure.

5. In this thesis the profile of the studied soil is within $1.5 \mathrm{~m}$ to $3 \mathrm{~m}$, thus detailed profile investigation should have to be carried out on soil samples that are under studies.

6. Finally, it is recommended that Cost benefit analysis should have to be made to use the soils as construction materials.

\section{References}

[1] Budhu, M., (2000). Soil Mechanics and Foundations. John Wiley and Sons, U.S America.

[2] Morin. (1975). Laterite and lateritic soils and other problem soils of the tropics.

[3] Arora, K. R., (2000). Soil mechanics and Foundation engineering Delhi, India.

[4] Murthy V, (2001). Principles of Soil Mechanics and Foundation Engineering. New Delhi: UBS Publishers' Distributors Ltd.

[5] Belayun B, (2012). Study some of Engineering properties of soil found in Asela. M.Sc. Thesis presented to School of graduate Studies, Addis Ababa University, Civil Engineering Department, Addis Ababa.

[6] Blight, G. E., (1997). mechanics of residual soils, A. A Balkema, the Netherlands. 
[7] Bowles, J. E., (1978). Engineering properties of Soil and their Measurement. McGraw Hill Book Company, U.S. America.

[8] Teferra, A., \& Leikun, M., (1999). Soil Mechanics. Addis Ababa: Addis Ababa University.

[9] AASHTO, (2004). Standard specifications for transportation materials and methods of sampling and testing. U.S America.

[10] Lyon Association Inc. 1971. "Lateritic and Laterite Soil and Other Problematic Soils of Africa" Kumasi, Ghana.

[11] Rahardjo. (1993). soil mechanics for unsaturated soil.
[12] Gidigasu, M. D., (1976)."Laterite Soil Engineering: Pedogenesis and Engineering Principles". Development in Geotechnical Engineering.

[13] Towensend. (1969). the influence of sesquioxides.

[14] ASTM. (2004). Special Procedures for Testing Soil and Rock for Civil Engineering purpose. U.S America.

[15] Casagrande, A., and Fadum, R. E. 1940. Notes on soil testing for engineering purposes. 